Kelola

\title{
KEPEMIMPINAN YANG MELAYANI DI SEKOLAH MENENGAH TINGKAT ATAS SWASTA KOTA SALATIGA
}

\author{
Handita Sari \\ Alumni Program Pasca Sarjana Magister Manajemen Pendidikan \\ FKIP-Universitas Kristen Satya Wacana Salatiga \\ handita.sari@ymail.com \\ Supramono \\ Program Pasca Sarjana Magister Manajemen Pendidikan \\ FKIP-Universitas Kristen Satya Wacana Salatiga \\ supramono@staff.uksw.edu
}

\begin{abstract}
This study aimed to describe the degree of servant leadership in Salatiga private high schools. This study used descriptive method in which the object of the research are three private schools in Salatiga. Data collection techniques used by spreading questionnaires to the three principals, teachers and employees at those shools and also with interview. Researched indicators arranged based on six characteristics of servant leadership: values people, develop people, build community, display authenticity, provide leadership, dan share leadership. The results of this study showed that the overall degree of servant leadership implementation in the high category. However, there are some indicators that lead to the medium category. School principals are advised to be willing to improve some of these characteristics by first tried to listen to others. The results of this study can be used as a reference on servant leadership in secondary education.
\end{abstract}

Keywords: leadership, leadership degree, servant leadership.

\section{PENDAHULUAN}

Pada saat publikasi jurnal yang berjudul Developing leaders for tomorrow: releasing system potential, Harris dan Townsend (2007) menyatakan bahwa banyak negara akan menghadapi penurunan potensi dalam kapasitas kepemimpinan kepala sekolah selama beberapa tahun kedepan. Padahal menurut Mulyasa (2011) sebagai komponen penting organisasi sekolah, kepala sekolah harus mampu memberikan layanan yang bermutu secara optimal. Terlebih saat ini dunia pendidikan diperhadapkan dengan berbagai permasalahan, tantangan dan persaingan antar lembaga pendidikan. Tingkat persaingan yang terjadi terbilang sangat kompleks dan beragam. 
Mengenai persaingan yang terjadi Mulyasa (2011) menyatakan bahwa persaingan antar lembaga pendidikan meliputi mutu pendidikan, layanan, kehadiran lembaga pendidikan baru, keragaman pilihan yang ditawarkan lembaga pendidikan, pencitraan, penerimaan murid, dan sebagainya. Kondisi persaingan tersebut dapat menjadikan lembaga pendidikan yang mampu bertahan menjadi unggul, namun bagi lembaga yang tidak mampu bertahan akan mengalami penurunan dalam hal mutu pendidikan (Suti, 2011). Selain itu, bagi lembaga pendidikan yang mampu bersaing akan mendapatkan jumlah murid yang sesuai dengan daya tampungnya, sebaliknya bagi lembaga pendidikan yang tidak mampu bersaing tidak dapat memenuhi daya tampung.

Dalam salah satu pernyataan yang ada di www.pikiran-rakyat.com dinyatakan bahwa kondisi nyata persaingan yang dihadapi lembaga pendidikan dapat kita lihat di berbagai daerah. Hingga saat ini ada beberapa SMA swasta yang meskipun belum ditutup namun jumlah murid yang diterima belum memenuhi daya tampungnya. Di Bekasi, hal yang sama juga dikeluhkan oleh sejumlah kepala sekolah SMA swasta yang mengalami kekurangan siswa. bahkan $95 \%$ sekolah swasta di Bekasi terancam bangkrut. Di Palembang, hal yang sama juga terjadi dimana dari total 516 sekolah swasta di kota tersebut, sekitar 60 persennya terancam tutup karena sulitnya menghadapi persaingan antar sekolah. Pada tahun 2005 beberapa sekolah menengah tingkat atas (SMA) swasta di Kota Salatiga ini juga mulai mengalami penurunan jumlah siswa baru bahkan SMA Dharma Putra akhirnya harus tutup sedangkan pada tahun 2007 SMA PGRI harus beralih menjadi SMK.

Untuk mengatasi kondisi tersebut, setiap lembaga pendidikan dituntut untuk melakukan berbagai penataan sehingga mampu bersaing dan dapat terus meningkat menjadi lebih baik. Salah satu penataan yang hendaknya dilakukan adalah penataan model kepemimpinan yang mampu mengembangkan SDM nya. Kepala sekolah sebagai pemimpin dalam organisasi sekolah memiliki peran penting yang mampu menguatkan aspek pemberdayaan guru dan karyawan. Hal tersebut didukung dengan pernyataan Mulyasa (2004) yakni keberhasilan pendidikan di sekolah sangat ditentukan oleh keberhasilan kepala sekolah dalam mengelola tenaga kependidikan yang tersedia di sekolah. Pemimpin atau kepala sekolah mempunyai wewenang untuk mengarahkan berbagai kegiatan para anggota atau kelompok.

Melihat kondisi diatas kita perlu merefleksikan kembali apa jenis kepemimpinan yang terbaik untuk kepala sekolah saat ini. Musakabe (2004) menyatakan bahwa kepemimpinan yang melayani (Servant leadership) merupakan suatu tipe atau model kepemimpinan yang dikembangkan untuk mengatasi permasalahan mengenai kualitas kepemimpinan. Hal ini 
karena perilaku yang dicerminkan dari seorang servant leaders cenderung menjadi teladan untuk mempengaruhi orang-orang yang dipimpinnya.

Sejalan dengan pandangan Mukasabe perlu kita perhatikan pula pandangan Greenleaf (1999) bahwa kita harus mau mengubah pandangan tentang pemimpin yang semula dipahami sebagai pahlawan yang serba tahu dan serba berkuasa menjadi "pemimpin yang pertama-tama dipandang sebagai pelayan". Pemimpin yang rela bukan karena paksaan mengorbankan dirinya sendiri demi orang lain. Pemimpin yang dapat menjadi berkat bagi anggotanya. Greenleaf juga menyatakan bahwa kepemimpinan yang melayani (Servant Leadership) yaitu sebuah pendekatan baru sebagai model kepemimpinan yang mencoba untuk secara simultan meningkatkan pertumbuhan personal dari para pekerja dan memperbaiki kualitas pelayanan dari organisasi melalui kombinasi atas kerjasama tim dan pengembangan komunitas, keterlibatan personal dalam proses pembuatan keputusan, serta perilaku yang peduli dan etis.

Konsep kepemimpinan yang melayani adalah mengubah pendekatan kepemimpinan secara evolusioner dan pribadi. Konsep ini bukanlah suatu perbaikan serba cepat atas persoalan-persoalan yang dihadapi pemimpin. Kepemimpinan pelayan menggunakan pendekatan mendasar dan bersifat jangka panjang, yang pada akhirnya akan memberikan perubahan secara menyeluruh pada kehidupan personal dan profesional pegawai (Astohar, 2012). Greenleaf dalam bukunya yang berjudul Servant Leadership menyebutkan bahwa kepemimpinan yang melayani adalah suatu kepemimpinan yang berawal dari perasaan tulus yang timbul dari dalam hati yang berkehendak untuk melayani, yaitu untuk menjadi pihak pertama yang melayani. Pilihan yang berasal dari suara hati itu kemudian menghadirkan hasrat untuk menjadi pemimpin. Perbedaan manifestasi dalam hal melayani yang diberikan, pertama adalah memastikan bahwa kebutuhan pihak lain dapat dipenuhi, yaitu menjadikan mereka sebagai orang-orang yang lebih dewasa, sehat, bebas, dan otonom, yang pada akhirnya dapat menjadi pemimpin yang melayani berikutnya.

Para peneliti mengindikasikan bahwa sebenarnya pemimpin yang melayani dapat dibentuk atau diciptakan (nurture) lewat berbagai pelatihan dan pengalaman dalam kurun waktu tertentu di masa hidupnya. Lantu, Pesiwarissa, \& Rumahorbo (2007), mengatakan: "seorang pemimpin yang bukanlah seorang yang telah dilahirkan untuk itu, tetapi diperlukan kerja keras dan lingkungan yang tepat untuk dapat belajar serta bertumbuh menjadi pemimpin yang efektif". Artinya perilaku kepribadian itu dapat dipelajari dan terus dikembangkan dengan tekad yang kuat.

Kepemimpinan yang melayani yang menurut Greenleaf dan Mukasabe mampu untuk mengatasi banyak permasalahan di sebuah organisasi belum banyak dilakukan penelitian 
didunia pendidikan khususnya sekolah tingkat menengah atas. Penelitian mengenai Servant Leadership di Indonesia masih didominasi di seputar perguruan tinggi, sedangkan di sekolah menengah tingkat atas (SMA) di Indonesia belum ditemukan. Padahal Servant Leadership dapat diterapkan disemua jenjang pendidikan termasuk sekolah menengah tingkat atas. Bahkan dengan maraknya penurunan kualitas dan kuantitas sebuah sekolah menengah tingkat atas swasta yang terjadi saat ini, seperti yang sudah dipaparkan sebelumnya menjadi dasar yang rasional mengapa penelitian ini akan dilakukan dengan obyek penelitian sekolah menengah tingkat atas. Penelitian ini akan dilakukan di tiga sekolah swasta yang memiliki potensi besar telah melaksanakan kepemimpinan servant leadership.

\section{METODE PENELITIAN}

Jenis penelitian yang dilakukan terhadap kepemimpinan kepala sekolah ini bersifat deskriptif yang bertujuan untuk menggambarkan derajat kepemimpinan yang melayani yang telah dilakukan oleh kepala sekolah dari sekolah menengah tingkat atas swasta kota Salatiga selama ini. Karakteristik servant leadership yang digunakan dalam penelitian ini dinyatakan oleh Laub (1999) merupakan alat pengukuran yang valid dalam menilai kepemimpinan yang melayani di setiap organisasi: value people, develop people, build community, display authenticity, provide leadership, dan share leadership. Obyek penelitian dalam penelitian ini adalah tiga sekolah menengah tingkat atas swasta kota Salatiga. Sumber data dalam penelitian ini adalah para responden yang terdiri dari kepala sekolah dan seluruh guru dan karyawan di tiga sekolah yang menjadi obyek penelitian yang berjumlah 38 orang. Teknik pengumpulan data dalam penelitian ada dua yakni angket, sedangkan sebagai kelengkapan data terutama untuk data yang masih meragukan kebenarannya dilakukan wawancara.

Dari data angket hasil penelitian yang telah dilakukan akan dianalisis dengan menggunakan metode statistik deskriptif. Alat pengukuran data yang digunakan adalah Skala Likert, dimana ada penggunaan skor untuk melihat pendapat para guru dan karyawan tentang implementasi kepemimpinan yang melayani. Dalam setiap pertanyaan terdapat skor yang memiliki nilai dalam setiap jawaban seperti berikut: Sangat Tidak Setuju (STS) diberi skor 1; Tidak Setuju (TS) diberi skor 2; Ragu-ragu (R) diberi skor 3; Setuju (S) diberi skor 4; Sangat Setuju (SS) skor 5. Dari data yang telah terkumpul ditentukan nilai mean yang kemudian hasilnya dibagi dalam lima kategori yaitu: sangat tinggi, tinggi, sedang, rendah, sangat rendah yang disajikan pada Tabel 1.

Tabel 1.

Kategori Penilaian derajat kepemimpinan yang melayani

\begin{tabular}{l|l|l}
\hline NO & RENTANG & KATEGORI \\
\hline
\end{tabular}




\begin{tabular}{|c|c|c|}
\hline 1 & $1.00-1.80$ & Sangat Rendah \\
\hline 2 & $1.81-2.60$ & Rendah \\
\hline 3 & $2.61-3.40$ & Sedang \\
\hline 4 & $3.41-4.20$ & Tinggi \\
\hline 5 & $4.21-5.00$ & Sangat Tinggi \\
\hline
\end{tabular}

\section{HASIL PENELITIAN DAN PEMBAHASAN}

\section{Hasil Penelitian}

Data statistik deskriptif pada Tabel 2. menunjukkan bahwa secara keseluruhan responden menilai bahwa karakteristik value people telah dilaksanakan dengan baik. Rasa menghargai guru dan karyawan itu ditunjukkan oleh perhatian yang sangat baik dari kepala sekolah terhadap kebutuhan guru dan karyawan serta dengan memberikan penghargaan yang layak. Namun demikian sikap kepala sekolah dalam hal mendengarkan guru dan karyawan secara empati dinilai responden masih belum maksimal.

Tabel 2. Statistik Deskriptif Variabel Value People

\begin{tabular}{|c|l|c|c|c|c|}
\hline \multirow{2}{*}{$\begin{array}{c}\text { N } \\
\mathbf{0}\end{array}$} & \multicolumn{1}{|c|}{ Pernyataan } & \multicolumn{3}{|c|}{ RESPONDEN } \\
\cline { 2 - 5 } & \multicolumn{1}{|c|}{ Min U \& KARAWAN } \\
\hline \hline 1 & $\begin{array}{l}\text { Kepala sekolah mempercayai guru dan karyawan dalam } \\
\text { melaksanakan tugas. }\end{array}$ & 2 & 5 & 3.64 & 0.652 \\
\hline 7 & $\begin{array}{l}\text { Kepala sekolah banyak mendengarkan guru dan karyawan secara } \\
\text { empati. }\end{array}$ & 2 & 5 & 3.38 & 0.963 \\
\hline 13 & $\begin{array}{l}\text { Kepala sekolah mengerti akan kebutuhan guru dan karyawan. } \\
\text { Kepala sekolah melayani kebutuhan guru dan karyawan terlebih } \\
\text { dahulu dibandingkan kebutuhan pribadinya. }\end{array}$ & 2 & 5 & 4.48 & 0.610 \\
\hline 25 & $\begin{array}{l}\text { Kepala sekolah memiliki pemahaman bahwa setiap guru dan } \\
\text { karyawan memiliki potensinya masing-masing. }\end{array}$ & 4 & 5 & 4.61 & 0.490 \\
\hline 31 & $\begin{array}{l}\text { Kepala sekolah akan memberikan penghargaan yang layak kepada } \\
\text { guru dan karyawan yang berprestasi. }\end{array}$ & 3 & 5 & 4.16 & 0.595 \\
\hline \multicolumn{1}{|c|}{ Rata-rata } & 2.50 & 5.00 & 4.01 & 0.630 \\
\hline
\end{tabular}

Sumber: Data penelitian diolah

Menurut responden, kepala sekolah sudah sangat baik didalam memberikan kesempatan kepada guru dan karyawan untuk belajar dan mengembangkan diri dengan berbagai upaya yang dilakukan termasuk sebagai mentor bagi guru dan karyawan. Hal itu terlihat dari nilai mean statistik deskriptif pada tabel 3 yang termasuk kategori sangat tinggi.

Tabel 3. Statistik Deskriptif Variabel Develop People

\begin{tabular}{|c|l|c|c|c|c|}
\hline \multirow{2}{*}{ No } & \multicolumn{1}{|c|}{ Pernyataan } & \multicolumn{3}{c|}{ RESPONDEN } \\
\cline { 3 - 6 } & \multicolumn{1}{|c|}{ GURU \& KARYAWAN } \\
\hline \hline 2 & $\begin{array}{l}\text { Kepala sekolah memberikan kesempatan kepada guru dan } \\
\text { karyawan untuk mengembangkan potensinya. }\end{array}$ & 4 & 5 & 4.66 & 0.477 \\
\hline 8 & $\begin{array}{l}\text { Kepala sekolah mengembangkan guru dan karyawan dengan } \\
\text { melayaninya sebagai mentor. }\end{array}$ & 3 & 5 & 4.47 & 0.525 \\
\hline
\end{tabular}




\begin{tabular}{|c|l|c|c|c|c|}
\hline 14 & $\begin{array}{l}\text { Kepala sekolah menciptakan lingkungan yang mendorong guru } \\
\text { dan karyawan untuk terus belajar. }\end{array}$ & 3 & 5 & 4.54 & 0.524 \\
\hline 20 & $\begin{array}{l}\text { Kepala sekolah memberikan kesempatan seluas-luasnya kepada } \\
\text { guru dan karyawan untuk memberikan ide-ide baru demi } \\
\text { kemajuan sekolah. }\end{array}$ & 4 & 5 & 4.64 & 0.484 \\
\hline 26 & $\begin{array}{l}\text { Kepala sekolah menjadi teladan terhadap perilaku yang } \\
\text { diinginkan. }\end{array}$ & 4 & 5 & 4.60 & 0.493 \\
\hline 32 & $\begin{array}{l}\text { Kepala sekolah mendorong guru untuk tidak cepat puas dengan } \\
\text { pekerjaannya. }\end{array}$ & 3 & 5 & 4.52 & 0.526 \\
\hline Rata-rata & 3.5 & 5 & 4.57 & 0.505 \\
\hline
\end{tabular}

Sumber: Data penelitian diolah

Nilai rata-rata keseluruhan variabel build community yang ditunjukkan oleh tabel 4 . dibawah adalah sebesar 4.13. Angka tersebut menunjukkan bahwa secara keseluruhan kepala sekolah memiliki kemampuan yang baik didalam membangun komunitas. Kepala sekolah dinilai telah mampu bekerjasama dengan semua guru dan karyawan, menghargai perbedaan, dan memfasilitasi bentuk kerjasama antar guru. Tetapi nampaknya dari enam variabel diatas ada satu yang bagi responden belum cukup baik dilakukan oleh kepala sekolah yaitu didalam membangun hubungan personal dengan guru dan karyawan.

Tabel 4. Statistik Deskriptif Variabel Build Community

\begin{tabular}{|c|l|c|c|c|}
\hline \multirow{2}{*}{ No } & \multicolumn{1}{|c|}{ Pernyataan } & \multicolumn{1}{|c|}{ RESPONDEN } \\
GURU \& KARYAWAN
\end{tabular}

Sumber: Data penelitian diolah

Tentang variabel Display Authenticity dari para Kepala Sekolah Tabel 5. memberi gambaran sebagai berikut.

Tabel 5. Statistik Deskriptif Variabel Display Authenticity

\begin{tabular}{|c|l|c|c|c|c|}
\hline \multirow{2}{*}{ No } & \multicolumn{2}{|c|}{ Pernyataan } & \multicolumn{4}{c|}{ RESPONDEN } \\
\cline { 3 - 6 } & & Min & Max & Mean & SD \\
\hline \hline 4 & Kepala sekolah terbuka menerima kritik. & 1 & 4 & 3.34 & 0.749 \\
\hline 10 & Kepala sekolah bersedia mengakui apabila memiliki kesalahan. & 2 & 4 & 3.41 & 0.695 \\
\hline
\end{tabular}




\begin{tabular}{|c|c|c|c|c|c|}
\hline 16 & $\begin{array}{l}\text { Kepala sekolah memiliki keinginan yang kuat untuk belajar dari } \\
\text { orang lain. }\end{array}$ & 2 & 5 & 3.41 & 0.729 \\
\hline 22 & Kepala sekolah mempertahankan integritas. & 2 & 4 & 3.42 & 0.643 \\
\hline 28 & $\begin{array}{l}\text { Kepala sekolah bersedia mengevaluasi diri sebelum menyalahkan } \\
\text { orang lain. }\end{array}$ & 2 & 4 & 3.41 & 0.745 \\
\hline 34 & $\begin{array}{l}\text { Kepala sekolah menentang apabila ada tindakan gegabah } \\
\text { menyalahkan orang lain. }\end{array}$ & 2 & 5 & 3.42 & 0.807 \\
\hline \multicolumn{2}{|r|}{ Rata-rata } & 1.83 & 4.33 & 3.40 & 0.730 \\
\hline
\end{tabular}

Sumber: Data penelitian diolah

Tabel 5 di atas memperlihatkan bahwa secara keseluruhan kepala sekolah dinilai oleh responden termasuk dalam kategori sedang. Responden merasa bahwa kepala sekolah belum maksimal dalam mengekspresikan diri untuk terbuka menerima kritikan. Namun kepala sekolah dinilai sudah baik dalam mempertahankan integritasnya. Responden juga merasa bahwa kepala sekolah adalah pribadi yang menentang adanya tindakan gegabah menyalahkan orang lain bahkan kepala sekolah juga bersedia mengakui kesalahan apabila bersalah.

Dalam Tabel 6. diperlihatkan bahwa kepala sekolah dinilai responden telah berhasil dengan sangat baik melaksanakan karaktersitik ke lima ini. Tabel ini menunjukkan bahwa kepala sekolah telah memberikan perspektif masa depan kepada para pengikut, memprakarsai dan mengambil inisiatif, berani mengambil resiko, serta sangat berkompeten.

Tabel 6. Statistik Deskriptif Variabel Provide Leadership

\begin{tabular}{|c|c|c|c|c|c|}
\hline \multirow{2}{*}{ No } & \multirow{2}{*}{ Pernyataan } & \multicolumn{4}{|c|}{$\begin{array}{c}\text { RESPONDEN } \\
\text { GURU \& KARYAWAN } \\
\end{array}$} \\
\hline & & Min & Max & Mean & SD \\
\hline 5 & $\begin{array}{l}\text { Kepala sekolah memberikan perspektif masa depan sekolah yang } \\
\text { jelas kepada guru dan karyawan. }\end{array}$ & 1 & 5 & 4.46 & 0.795 \\
\hline 11 & $\begin{array}{l}\text { Kepala sekolah mendorong guru dan karyawan untuk bekerja tanpa } \\
\text { keterpaksaan. }\end{array}$ & 2 & 5 & 4.58 & 0.624 \\
\hline 17 & $\begin{array}{l}\text { Kepala sekolah mampu mengubah hal negatif menjadi positif } \\
\text { (ancaman menjadi peluang). }\end{array}$ & 3 & 5 & 4.42 & 0.543 \\
\hline 23 & Kepala sekolah memiliki visi kedepan yang jelas. & 4 & 5 & 4.61 & 0.490 \\
\hline 29 & $\begin{array}{l}\text { Kepala sekolah memiliki keberanian mengambil resiko demi } \\
\text { kemajuan sekolah. }\end{array}$ & 3 & 5 & 4.51 & 0.610 \\
\hline 35 & $\begin{array}{l}\text { Kepala sekolah berkompeten (memiliki pengetahuan dan } \\
\text { keterampilan) untuk menyelesaikan segala sesuatu. }\end{array}$ & 4 & 5 & 4.59 & 0.495 \\
\hline & Rata-rata & 2.83 & 5.00 & 4.53 & 0.593 \\
\hline
\end{tabular}

Sumber: Data penelitian diolah

Melalui tabel 7 dibawah terlihat bahwa kepala sekolah telah melibatkan guru dan karyawan dalam penyusunan visi dan misi sekolah.

Tabel 7. Statistik Deskriptif Variabel Share Leadership

\begin{tabular}{|c|l|c|c|c|c|}
\hline \multirow{2}{*}{ Pernyatan } & \multicolumn{4}{|c|}{ RESPONDEN } \\
\cline { 3 - 5 } No & \multicolumn{1}{|c|}{ GURU \& KARYAWAN } \\
\hline \hline 6 & $\begin{array}{l}\text { Kepala sekolah melibatkan guru dan karyawan dalam menyusun } \\
\text { visi dan misi sekolah. }\end{array}$ & 2 & 5 & 4.53 & 0.569 \\
\hline
\end{tabular}




\begin{tabular}{|c|l|c|c|c|c|}
\hline 12 & $\begin{array}{l}\text { Kepala sekolah sering mendelegasikan hal-hal penting kepada } \\
\text { wakil-wakilnya apabila ada tugas keluar. }\end{array}$ & 1 & 4 & 3.11 & 1.155 \\
\hline 18 & $\begin{array}{l}\text { Kepala sekolah melakukan pelimpahan tugas kepada beberapa } \\
\text { orang guru di bidang kurikulum, kesiswaan, sarpras, humas, dan } \\
\text { keuangan. }\end{array}$ & 3 & 5 & 4.41 & 0.519 \\
\hline 24 & $\begin{array}{l}\text { Kepala sekolah bukan mencari status ataupun mengutamakan } \\
\text { tunjangan pemimpin. }\end{array}$ & 3 & 5 & 4.42 & 0.520 \\
\hline 30 & $\begin{array}{l}\text { Kepala sekolah tidak mengharapkan penghormatan dalam } \\
\text { memimpin. }\end{array}$ & 1 & 5 & 4.00 & 0.655 \\
\hline 36 & $\begin{array}{l}\text { Kepala sekolah rendah hati (tidak mengunggul-unggulkan dirinya } \\
\text { sendiri). }\end{array}$ & 2 & 4 & 3.40 & 0.710 \\
\hline \multicolumn{1}{|l|}{ Rata-rata } & 2.00 & 4.67 & 3.98 & 0.688 \\
\hline
\end{tabular}

Sumber: Data penelitian diolah

Walaupun responden menilai bahwa kepala sekolah telah melibatkan guru dan karyawan dalam penyusunan visi dan misi sekolah, namun responden merasa bahwa kepala sekolah belum cukup rendah hati dan masih mengunggulkan diri sendiri.

Data statistik deskriptif pada tabel 8. dibawah menunjukkan bahwa penilaian dari guru dan karyawan sedikit berbeda dengan penilaian dari kepala sekolah. Dimana menurut guru dan karyawan derajat pelaksanaannya termasuk dalam kategori tinggi sedangkan menurut kepala sekolah termasuk dalam kategori sangat tinggi. Selanjutnya menurut guru dan karyawan ada dua karakteristik yang paling menonjol dari yang lainnya yakni develop people dan provide leadership. Selain itu terdapat beberapa hal yang dirasa oleh guru dan karyawan belum cukup baik yaitu mengenai kesediaan mendengarkan secara empati pada karakteristik value people, membangun hubungan personal pada karakteristik build community, sikap terbuka menerima kritik pada karakteristik display authenticity, serta sikap rendah hati pada karakteristik share leadership. Sedangkan nilai standar deviasi secara keseluruhan sebesar 0.623 menunjukkan bahwa variasi jawaban responden relatif kecil atau tidak bervariasi. Hal ini berarti jawaban responden menyebar ke dalam enam kategori dengan kecenderungan yang sama.

Tabel 8. Rata-rata Statistik Deskriptif Enam Karaktersitik

\begin{tabular}{|c|c|c|c|c|c|c|c|c|c|}
\hline \multirow{2}{*}{ No. } & \multirow{2}{*}{ Indikator empiric } & \multicolumn{6}{|c|}{ RESPONDEN } \\
\cline { 3 - 10 } & & \multicolumn{2}{|c|}{ KEPALA SEKOLAH } & \multicolumn{2}{c|}{ GURU \& KARYAWAN } \\
\cline { 2 - 10 } & & Min & Max & Mean & Sd & Min & Max & Mean & Sd \\
\hline \hline 1 & VALUE PEOPLE & 4.33 & 5.00 & 4.78 & 0.385 & 2.50 & 5.00 & 4.01 & $\begin{array}{c}0.63 \\
0\end{array}$ \\
\hline 2 & DEVELOP PEOPLE & 4.33 & 5.00 & 4.78 & 0.385 & 3.50 & 5.00 & 4.57 & $\begin{array}{c}0.50 \\
5\end{array}$ \\
\hline 3 & BUILD COMMUNITY & 4.67 & 4.50 & 4.89 & 0.192 & 2.67 & 4.50 & 4.06 & $\begin{array}{c}0.59 \\
0\end{array}$ \\
\hline 4 & DISPLAY AUTHENTICITY & 4.67 & 4.50 & 4.89 & 0.192 & 1.83 & 4.33 & 3.40 & $\begin{array}{c}0.73 \\
0\end{array}$ \\
\hline 5 & PROVIDE LEADERSHIP & 4.33 & 5.00 & 4.78 & 0.385 & 2.83 & 5.00 & 4.53 & $\begin{array}{c}0.59 \\
3\end{array}$ \\
\hline
\end{tabular}


Kepemimpinan Yang Melayani Di Sekolah Menengah Tingkat Atas Swasta Kota Salatiga

\begin{tabular}{|c|c|c|c|c|c|c|c|c|c|}
\hline 6 & SHARE LEADERSHIP & 3.83 & 4.83 & 4.45 & 0.552 & 2.00 & 4.67 & 3.98 & $\begin{array}{c}0.68 \\
8\end{array}$ \\
\hline Rata-rata & 4.36 & 4.81 & 4.76 & 0.349 & 2.56 & 4.75 & 4.09 & $\begin{array}{c}0.62 \\
3\end{array}$ \\
\hline
\end{tabular}

Sumber: Data penelitian diolah

\section{Pembahasan}

Secara keseluruhan kepala sekolah dipandang telah melaksanakan kepemimpinan yang melayani dengan derajat pelaksanaannya tinggi. Namun demikian masih ada beberapa hal yang dipandang belum maksimal oleh para responden. Hasil diatas sejalan dengan hasil penelitian Aurora (2009) yang menunjukkan bahwa kepemimpinan di IPB juga belum dapat melaksanakan semua karakteristik servant leadership dengan maksimal. Mereka hanya melaksanakan lima dari sepuluh karakteristik yang diteliti.

Selanjutnya penelitian Foster (2002) menemukan bahwa salah satu faktor penghambat keberhasilan kepemimpinan yang melayani adalah proses komunikasi dan kolaborasi yang tidak efektif, nampaknya proses komunikasi dan kolaborasi antara kepala sekolah dengan guru dan karyawan juga masih kurang efektif. Hal ini terlihat dari penilaian responden terhadap kepala sekolah yang dinilai kurang maksimal dalam hal mendengarkan secara empati dan juga dalam hal membangun hubungan personal. Hasil wawancara dengan kepala sekolah menyatakan bahwa mereka sesungguhnya merasakan kekurangan waktu untuk melakukannya secara maksimal. Untuk membangun hubungan personal yang kuat dan mendengarkan secara empati terhadap setiap guru dan karyawan terlebih personal yang sedang menghadapi masalah. Mengapa menjadi sulit karena begitu banyaknya tugas dan tanggung jawab seorang kepala sekolah yang sangat menyita waktu terlebih di sekolah swasta dimana seorang kepala sekolah harus mampu berpikir lebih keras untuk dapat terus mempertahankan eksistensi sekolah.

Selain dua hal diatas masih ada karakteristik kepemimpinan yang melayani yang dinilai oleh responden belum maksimal dilakukan oleh kepala sekolah yakni karakteristik display authenticity. Authenticity berkaitan erat dengan ungkapan "true self", bagaimana seorang pemimpin yang melayani mengekspersikan diri dengan cara yang konsisten dalam hal pikiran dan perasaaan (Harter, 2002). Menurut Laub (1999) Display Authenticity dapat ditunjukkan melalui sikap bertanggung jawab dan terbuka kepada orang lain termasuk terbuka menerima kritikan, bersedia mengakui apabila memiliki kesalahan, memiliki keinginan yang kuat untuk belajar dari orang lain, mempertahankan integritas dan sifat dapat dipercaya. Kepala sekolah berada pada kategori sedang dalam menunjukkan display authenticity karena dari enam variabel secara keseluruhan memiliki mean yang berada pada kategori sedang. 
Sikap terbuka dalam menerima kritik belum terlaksana dengan baik karena memang menurut peneliti pada umumnya manusia itu sangat sulit menerima kritikan. Pemimpin yang baik pasti ikhlas mendengarkan kritik terhadap dirinya oleh siapapun termasuk oleh anak buahnya. Pemimpin harus mengakui manfaat dari kritik, lalu berpikir positif dan berani mengevaluasi diri untuk mengembangkan reputasi baik dalam menangani semua kritikan dan rasa tidak puas agar dapat meraih simpati dari para pengritik.

Pemimpin yang melayani seharusnya berani mengakui bahwa mereka dapat bekerja dengan baik karena ada campur tangan dari orang lain, yaitu para anggota dan bukan bekerja sendiri untuk mendapatkan hasil yang terbaik. Pendapat ini sesuai dengan ungkapam Patterson \& Seligman (2004) yakni bahwa seseorang dapat dikatakan sebagai pemimpin yang melayani jika dan hanya jika ia memiliki sifat rendah hati. Bahkan jika upaya yang dilakukan mendatangkan keberhasilan maka seorang kepala sekolah akan menyatakan kepada semua orang yang ditemuinya bahwa keberhasilan itu adalah hasil kerja keras guru dan karyawan atau karena faktor eksternal saja. Berkaitan dengan uraian diatas nampaknya responden masih merasa bahwa kepala sekolah belum cukup baik dalam hal bersikap rendah hati bahkan masih memiliki sikap mengunggulkan diri sendiri. Sikap rendah hati dan tidak mengunggulkan diri sendiri seringkali susah dilaksanakan oleh seorang kepala sekolah dikarenakan semua kegiatan di sekolah tersentral pada kepemimpinan kepala sekolah, segala hasil kegiatan berada dibawah tanggung jawab kepala sekolah baik yang berupa keberhasilan maupun kegagalan sekolah berada dibawah tanggung jawab kepala sekolah sehingga seringkali seorang kepala sekolah merasa bahwa dialah yang paling berjasa dalam setiap kegiatan yang ada di sekolah.

\section{SIMPULAN DAN SARAN}

\section{Simpulan}

Berdasarkan pembahasan hasil penelitian pada bab sebelumnya, maka peneliti dapat menarik kesimpulan bahwa derajat kepemimpinan yang melayani (servant leadership) di sekolah menengah tingkat atas swasta kota Salatiga sudah tinggi atau baik. Hal ini ditunjukkan dengan pelaksanaan enam karakteristik kepemimpinan yang melayani secara keseluruhan termasuk dalam kategori tinggi atau baik. Ada dua karakteristik yang sangat menonjol yakni develop people dan provide leadership. Namun ada beberapa hal yang dipandang belum maksimal dilakukan oleh kepala sekolah yakni kepala sekolah dinilai kurang maksimal dalam hal mendengarkan secara empati dan juga dalam hal membangun hubungan personal, kurang terbuka dalam menerima kritik, serta masih memiliki sikap mengunggulkan diri sendiri. 


\section{Saran}

Berdasarkan hasil temuan, pembahasan dan kesimpulan yang diperoleh, maka kepala sekolah dinilai belum maksimal dalam melakukan beberapa karakteristik kepemimpinan yang melayani. Untuk mengatasi kelemahan karakter diatas disarankan setiap kepala sekolah dituntut untuk lebih sabar dan terus melatih kemampuan dalam mendengarkan orang lain, serta memiliki filosofi bahwa keberhasilan adalah milik bersama dan kegagalan adalah milik seorang pemimpin. Bagi sekolah khususnya kepada guru dan karyawan harus lebih meneladani keteladanan positif yang sudah diteladankan oleh kepala sekolah terutama dalam hal kepemimpinan yang melayani. Selain itu guru dan karyawan juga harus banyak belajar melalui pelatihan untuk terus mengembangkan kualitas pelayanannya terhadap warga sekolah seperti misalnya bersedia bekerja sama dengan tulus, rela berkorban, dan memiliki sikap lebih perduli lagi terhadap eksistensi sekolah.

Penelitian ini bersifat spesifik karena baru diterapkan di tiga sekolah menengah tingkat atas swasta kota Salatiga. Oleh karena itu hasil penelitian ini mungkin belum bisa langsung digeneralisasikan pada sekolah-sekolah yang lain. Selain itu penelitian ini belum dilakukan secara mendalam karena hanya meneliti derajat pelaksanaan kepemimpinan yang melayani belum meneliti tentang dampaknya bagi sekolah. Dengan demikian diharapkan penelitian selanjutnya dapat diteliti dampaknya bagi sekolah.

\section{Daftar Pustaka}

Aorora, D. 2009. Skripsi : Model kepemimpinan Servant Leadership pada Institut Pertanian Bogor. Bogor : Departemen Manajemen Fakultas Ekonomi dan Manajemen, IPB.

Astohar, 2012. Kepemimpinan Pelayan (Servant Leadership) sebagai gaya kepemimpinan untuk kemajuan organisasi. STIE Totalwin Semarang : Jurnal Ilmu Manajemen dan Akuntansi Terapan.

Greenleaf. R.K. 1999. On becoming a servant-leader. San Fransisco: Josey-Bass Publishers

Foster. A.B. 2002. Barriers to Servant Leadership: Perceived Organizational Elements that Impede Servant Leader Effevtiveness. Ann Arbor, Mich: UMI

Harris, A., \& Townsend, A. 2007. Journal : Developing leaders for tomorrow : Releasing system potential. School leadership and management.

Harter, J.K., Schmidt, F.L., \& Hayes, T. L., 2002. Business-unit level relationship between employee satisfaction, employee engagement, and business outcomes: A metaanalysis. Journal of Applied Psychology.

Lantu, Pesiwarissa, \& Rumahorbo. 2007. Servant Leadership : The Ultimate Calling to Fulfill Your Life's Greatness. Yogyakarta : Gradien Books.

Laub, J. 1999. Dissertation :Assessing The Servant Organization: Development Of The Organizational Leadership Assessment (OLA) Instrument. Florida Atlantic University, Boca Raton, Florida. 
Musakabe. H. 2004. Mencari Kepemimpinan Sejati, di tengah Krisis dan Reformasi. Jakarta: Penerbit Citra Insan Pembaru

Mulyasa, E. 2011. Manajemen Berbasis Sekolah: Konsep, Strategi, dan Implementasi. Bandung: Rosdakarya.

Peterson, C. \& Seligman, E. P. M., 2004. Character Strengths and Virtues, A Handbook and Classification. American Psychological Association. New York : Oxford University Press.

Suti, Marus. 2011. Strategi Peningkatan Mutu Di Era Otonomi. Pendidikan. Jurnal MEDTEK, Volume 3 Nomor 2.

\section{Sumber lainnya:}

95 Persen sekolah swasta di kota Bekasi terancam bangkrut. Sumber: www.pikiranrakyat.com. Dipublikasi 3 Agustus 2012, diunduh 4 Juni 2015.

60 Persen sekolah swasta terancam tutup. Sumber: www.palembangnews.com. 